\title{
KERAN OTOMATIS SEBAGAI SOLUSI PENERAPAN PERILAKU HIDUP BERSIH DAN SEHAT DI MADRASAH IBTIDAIYAH MUHAMMADIYAH 1 BEJI TIMUR DEPOK
}

\author{
Toto Supriyanto $^{1 凶}$, Rifqi Fuadi Hasani ${ }^{2}$, Shita Fitria Nurjihan ${ }^{3}$, Ir. Sutanto ${ }^{4}$ \\ ${ }^{1,2,3,4}$ Program Studi Teknik Telekomunikasi. Jurusan Teknik Elektro. Politeknik Negeri Jakarta (PNJ) \\ Jl. Prof. DR. G.A. Siwabessy, Kampus Universitas Indonesia Depok 16425 \\ $\bigotimes_{e-m a i l:{ }^{1} \text { toto.supriyanto@elektro.pnj.ac.id }}$
}

\begin{abstract}
Covid-19 pandemic has affected the education sector. Having implemented physical distancing policy to stop virus transmission in the second semester of 2019-2020 made learning from home policy for school children by using internet access. Almost all schools undergo learning from home during pandemic covid-19 including schools in Depok, West Java. To protect student health conditions returning study at school, infrastructure for health and clean sanitary system must be strengthened. The telecommunication study program of the Electronic Engineering department of Politeknik Negeri Jakarta offers electric washing hand tools or electric washbasin at Islamic Madrasa Muhammadiyah 1, Beji Timur Depok. This elementary school is a partner for the community development program of the study program. Washbasins are placed in front of classes equipped with a water tap as well as an appropriate drainage system. Water tap is built by using an infrared sensor which is based on microcontroller Atmega 328p. This electric water tap enables students and teachers to wash their hands merely by getting closer their hands on the water tap. Water will be poured and be stopped automatically.
\end{abstract}

Keywords -Covid-19, electric water tap, health system, washbasin.

\begin{abstract}
Abstrak
Akibat adanya pandemi virus Corona yang disebut COVID-19, dunia pendidikan ikut terdampak akibatnya. Dengan berlakunya Lock down dan Physical distancing, pada semester genap 2019-2020 pembelajaran dilakukan dari rumah dengan menggunakan bantuan teknologi internet. Hampir semua sekolah melakukan hal yang sama, apalagi Depok yang masuk zona merah dari pandemi COVID19. Siswa dapat hidup sehat dengan adanya sarana prasarana di rumah masing-masing, misalkan untuk cuci tangan menggunakan sabun dan air mengalir. Setelah pandemi kebiasan hidup sehat harus tetap dilanjutkan. Pembelajaran kembali ke model semula yaitu face to face. Sarana prasarana PHBS harus disiapkan disekolah. Program studi Telekomunikasi Jurusan Teknik Elektro menawarkan membuat tempat cuci tangan atau wastafel di Madrasah Ibtidaiyah Muhammadiyah 1 Beji Timur sebagai mitra pelaksanaan pengabdian kepada masyarakat program studi. Wastafel dipasang di depan kelas dilengkapi dengan keran air dan pembuangan air yang benar. Untuk menerapkan keilmuannya dalam bidang teknik elektro, pelaksanaan pengabdian kepada masyarakat berbasis program studi Telekomunikasi ini dibuat keran otomatis menggunakan sensor infra red berbasis mikrokontroler Atmega 328p. Dengan keran otomatis ini jika ingin mencuci tangan cukup dekatkan tangannya kepada sensor, dan otomatis air akan keluar. Jika tangan dijauhkan dari sensor otomatis air akan berhenti mengalir. Jadi tidak perlu untuk membuka keran secara manual.
\end{abstract}

Kata Kunci-covid, keran otomatis, PHBS, wastafel.

\section{Pendahuluan}

Indonesia sedang dirundung duka. Awal tahun 2020 terjadi bencana alam, dengan adanya banjir baik dikota besar maupun di desa. Setelah banjir, bulan Maret 2020 muncul wabah virus Corona yang mematikan manusia. Gejala virus corona dimulai dengan batuk kering dan diikuti dengan gangguan pernafasan. Batuk ini adalah batuk yang terus menerus selama lebih dari satu jam, atau mengalami batuk rejan selama tiga kali dalam periode 24 jam. Gejala tersebut ditunjukkan rata-rata lima hari atau lebih. Organisasi Kesehatan Dunia, WHO mengatakan masa inkubasi dari COVID sampai sekitar 14 hari.

Virus Corona belum ada vaksin pencegahannya. Untuk mengurangi efek penyebaran anjuran cara-cara 
pencegahan yang terbaik dengan melakukan :

a. Mencuci tangan secara rutin dengan gel pembersih berbasis alkohol atau sabun dan bilas dengan air;

b. Menutup hidung dan mulut dengan tisu atau batuk dan bersin pada bagian dalam siku;

c. Hindari interaksi fisik (1 meter atau 3 kaki) dengan siapa pun yang memiliki gejala batuk pilek atau flu.

Dari uraian diatas, dunia pendidikan tentunya juga terkena dampak dari COVID19. Dengan berlakunya Lock down dan Physical distancing, pada semester genap 20192020 pembelajaran dilakukan dari rumah dengan menggunakan bantuan teknologi internet. Hampir semua sekolah melakukan hal yang sama, apalagi Depok yang masuk zona merah dari pandemi COVID19. Siswa dapat hidup sehat dengan adanya sarana prasarana di rumah masing-masing, misalkan untuk cuci tangan menggunakan sabun dan air mengalir. Setelah pandemik kebiasaan hidup sehat harus tetap dilanjutkan. Pembelajaran kembali ke model semula yaitu face to face. Sarana prasarana PHBS harus disiapkan disekolah.

Aktifitas perilaku hidup bersih dan sehat (PHBS) di sekolah mencuci tangan dengan air yang mengalir dan menggunakan sabun serta menggunakan jamban yang bersih dan sehat, dapat diterapkan jika infrastruktur yang dibutuhkan tersedia di sekolah. Seperti adanya kamar mandi disekolah, adanya sumber air bersih untuk bersih-bersih setelah Buang Air Kecil dan BAB pada tempat yang disediakan, tersedianya keran air untuk mencuci tangan dengan air mengalir, serta adanya aliran pembuangan limbah air yang benar. Fasilitas ini semestinya tersedia pada setiap sekolah sehingga PHBS dapat diterapkan di sekolah.
Program studi Telekomunikasi Jurusan Teknik Elektro Politeknik Negeri Jakarta (PNJ) tergerak untuk melakukan pengabdian kepada masyarakat pada sekolah disekitar wilayah kampus PNJ, sebagai salah satu tugas dosen dalam menjalankan Tridharma Perguruan Tinggi. Berdasarkan hasil survey, dipilih sekolah Madrasah Ibtidaiyah Muhammadiyah 1 (MIM1) Beji Timur sebagai mitra pelaksanaan pengabdian kepada masyarakat. Hasil komunikasi dengan Kepala Sekolah MIM1 Beji Timur diketahui bahwa sekolah tersebut belum ada sarana cuci tangan menggunakan air mengalir. Selama ini yang telah dilakukan oleh sekolah adalah menyediakan ember untuk cuci tangan per kelas. Kuman atau mikroba bisa mati jika tangan dicuci menggunakan sabun dengan cara yang benar. Menurut data WHO (2014), mencuci tangan dengan sabun dapat mengurangi $40 \%$ risiko diare, dan $20 \%$ risiko infeksi saluran pernapasan akut, termasuk pneumonia. Tetapi bila mencuci tangan didalam wadah bersama, kuman malah akan kumpul pada wadah tersebut.

Program yang dilakukan adalah membuat tempat cuci tangan atau wastafel. Wastafel disambungkan dengan sumber air melalui pipa PVC. Perlu dibuat instalasi air bersih dari sumber air hingga ke wastafel. Wastafel tersebut dipasang didepan ruang kelas, sehingga memudahkan siswa untuk cuci tangan dalam menerapkan PHBS. Air pembuangan akan dialirkan pada satu tempat, dimana air pembuangan tersebut tidak akan mencemari sekitar.

Selain itu perlu dibuat suatu keran agar sebisa mungkin jika ingin mencuci tangan siswa tidak perlu memutar keran tetapi cukup mendekatkan tangannya ke sensor dan air otomatis akan mengalir. Dan sebaliknya jika tangan di jauhkan dari sensor, air otomatis berhenti mengalir. Untuk mendukung dan mengedepankan program Pengabdian 
kepada Masyarakat PNJ yaitu menerapkan ipteks bagi masyarakat dalam bidang pembangunan, program studi Telekomunikasi jurusan teknik Elektro sesuai dengan bidang ilmunya membuat keran otomatis menggunakan sensor infra red (IR) berbasis mikrokontroler Atmega 328p.

\section{Metode Pengabdian}

akukan adalah:

a. Kegiatan persiapan, meliputi:

1. Koordinasi dengan Pihak Sekolah di lokasi Mitra;

2. Survey kondisi sekolah dilanjut diskusi dengan Mitra tentang permasalahan utama yang dihadapi Mitra;

3. Diskusi anggota pelaksana tentang metode dan solusi penyelesaian permasalahan Mitra;

4. Diskusi dengan Mitra (pihak sekolah) tentang solusi yang ditawarkan Tim Pelaksana.

b. Kegiatan pelaksanaan, meliputi:

1. Koordinasi dengan anggota Tim Pelaksana tentang pembagian tugas kegiatan;

2. Koordinasi dengan Mitra (pihak sekolah) untuk menyepakati PHBS, jumlah pekerja, dan lama waktu pelaksanaan pekerjaan;

3. Koordinasi dengan anggota Tim Pelaksana selama pelaksanaan pekerjaan.

c. Kegiatan evaluasi, meliputi:

1. Evaluasi tentang jumlah material, jumlah pekerja dan kendala-kendala yang dihadapi selama pembangunan.

2. Monitoring pasca renovasi dengan melibatkan mitra.

Selanjutnya tim pelaksana melakukan proses pengerjaan membuat keran otomatis yang akan di pasang di sekolah mitra. Untuk mempermudah pemahaman tentang perancangan keran otomatis dengan menggunakan sensor IR berbasis mikrokontroler ini, dibuat diagram Blok perancangan seperti Gambar 1. Perancangan keran otomatis ini meliputi perancangan rangkaian mikrokontroler, sensor IR, motor servo yang akan dipasangkan pada keran, dan catu daya. Catu daya berguna sebagai sumber tegangan untuk sistem minimum mikrokontroler, sensor, dan motor servo.

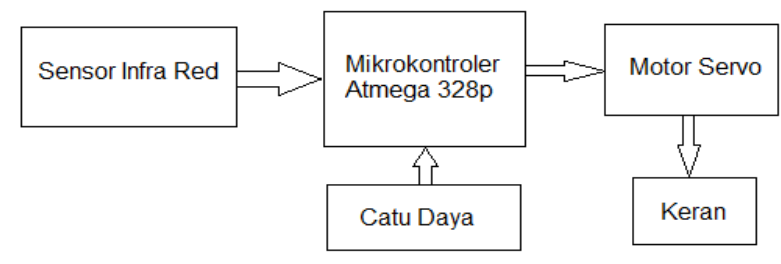

Gambar 1. Diagram Blok Sistem Keran Otomatis

Keran air otomatis ini memerlukan catu daya dari adaptor yang sumber daya nya langsung diambil dari jala-jala PLN. Keran ini menggunakan pemancar dan penerima sensor IR. Saat sensor mendeteksi adanya tangan di bawah keran, pemancar IR mengirimkan cahaya IR ke objek dan ketika sesuatu menghalangi cahaya tersebut maka objek akan memantulkan kembali cahaya ke penerima. Resistansi dari penerima berkurang dengan meningkatnya cahaya IR. Output penerima IR diolah oleh minimum sistem Mikrokontroler dan membandingkannya dengan nilai preset. Jika input mikrokontroler Atmega 328p menerima lebih banyak cahaya dibandingkan dengan ambang yang telah ditetapkan maka mikrokontroler akan mengirim sinyal ke motor servo, kemudian memutar kenop keran air.

Membuat mikrokontroler ATmega328P sesuai diagram blok sistem digunakan untuk unit pengendali utama keran otomatis. Mikrokontroler ini dapat diprogram menggunakan Arduino Uno. Kristal $16 \mathrm{MHz}$ eksternal digunakan sebagai sumber clock. Selain itu juga menambahkan 1 tombol untuk mengontrol saklar secara manual. Jika menekan tombol untuk pertama kalinya saklar akan aktif dan jika kembali menekan tombol saklar akan mati. Modul mikrokontroler diperlihatkan 
pada Gambar 2. Gambar 3 memperlihatkan diagram alir cara kerja sistem keran otomatis.

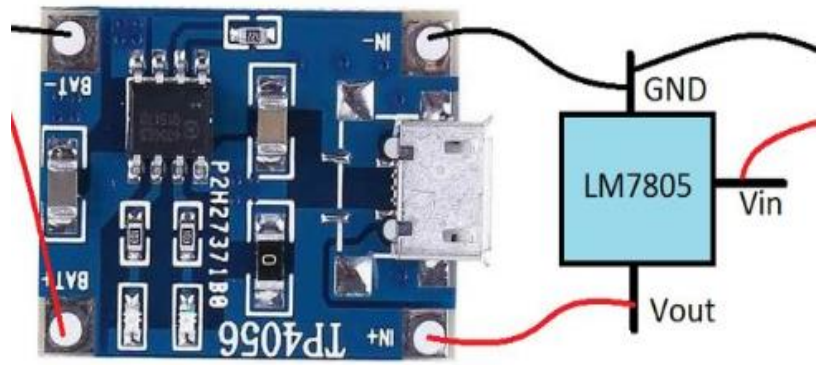

Gambar 2. Modul Mikrokontroler [1]

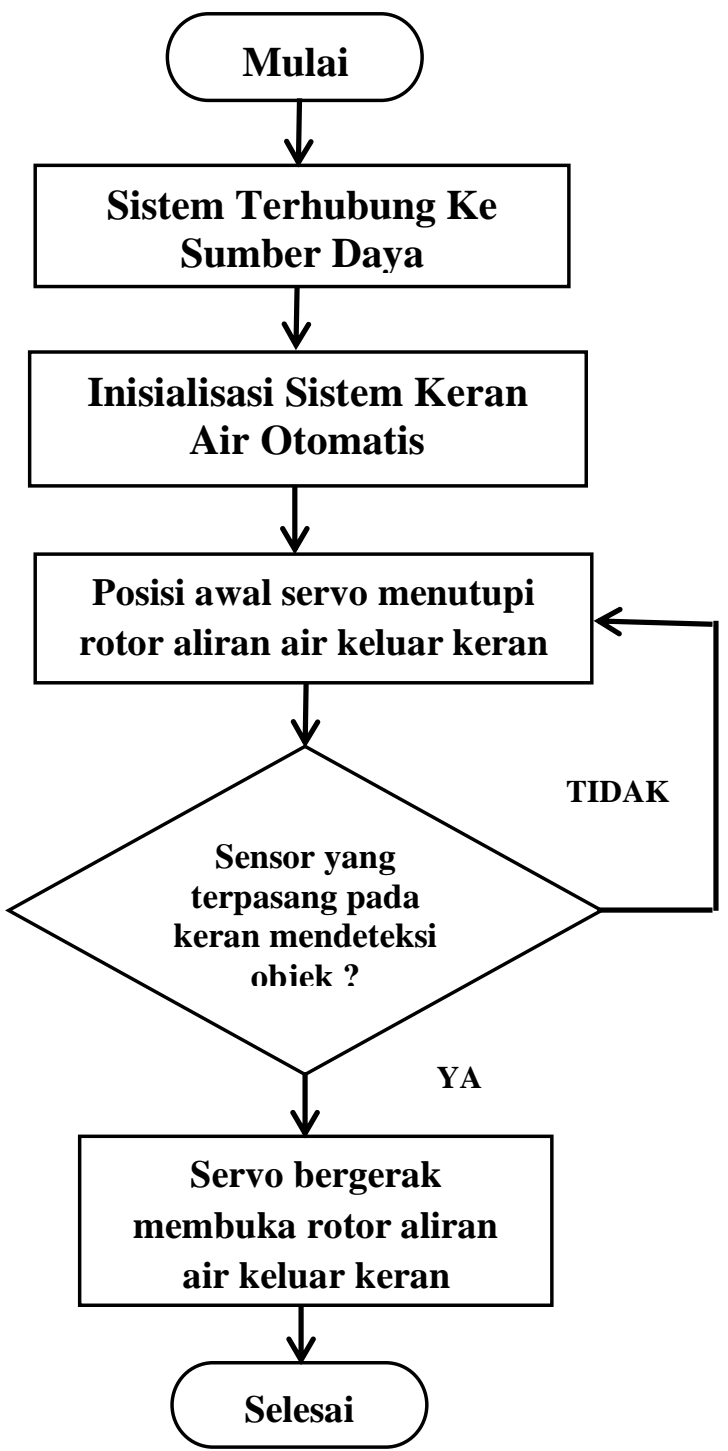

Gambar 3. Diagram Alir Sistem Keran Otomatis

\section{Hasil dan Pembahasan}

Hasil perancangan diperoleh sebagai berikut:

a. Membuat Keran Air Otomatis

i. Melepaskan penutup dan pembuka keran air.

ii. Memasang servo ke sumbu rotor keran air menggunakan lem yang kuat.

iii. Mengambil 2 inchi pipa plastik dengan diameter 1,25 inchi.

iv. Memotong pipa di satu sisi sesuai dengan ukuran servo dimana untuk meletakkan servo di atasnya.
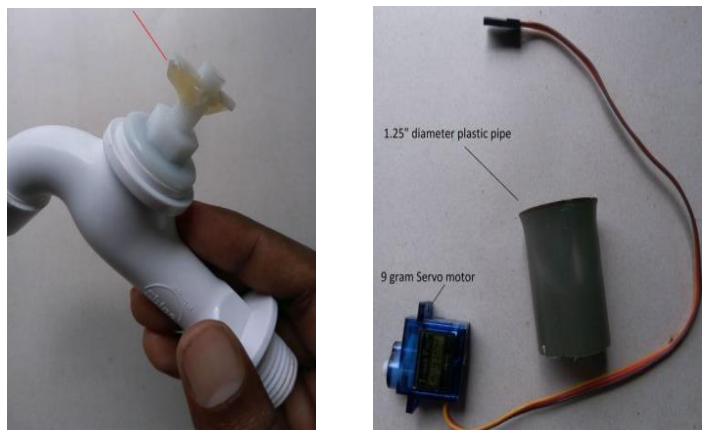

Gambar 4. Modifikasi keran air dengan Servo

b. Menyesuaikan ukuran servo ke Pipa

Memastikan pipa cocok dengan kepala servo yang telah dimodifikasi, diperlihatkan pada Gambar 5.

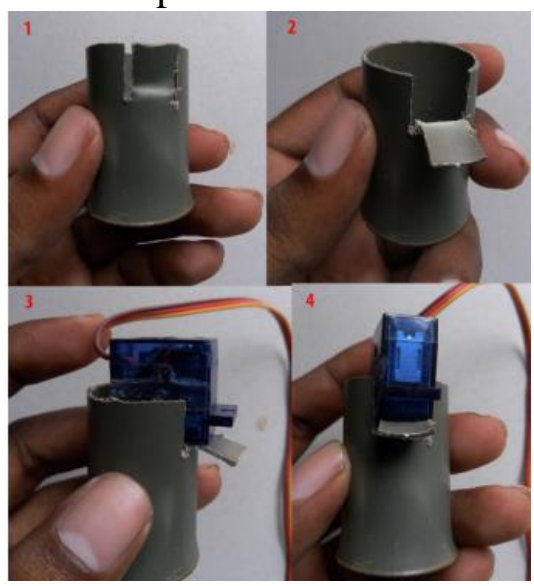

Gambar 5. Menyesuaikan ukuran pipa dengan kepala servo

c. Merekatkan Pipa Servo ke keran air 
Merekatkan pipa servo ke keran air menggunakan lem tembak. Lem digunakan semua sisi untuk menghubungkan dengan kuat dan mencegah masuknya air ke dalamnya, seperti pada Gambar 6.

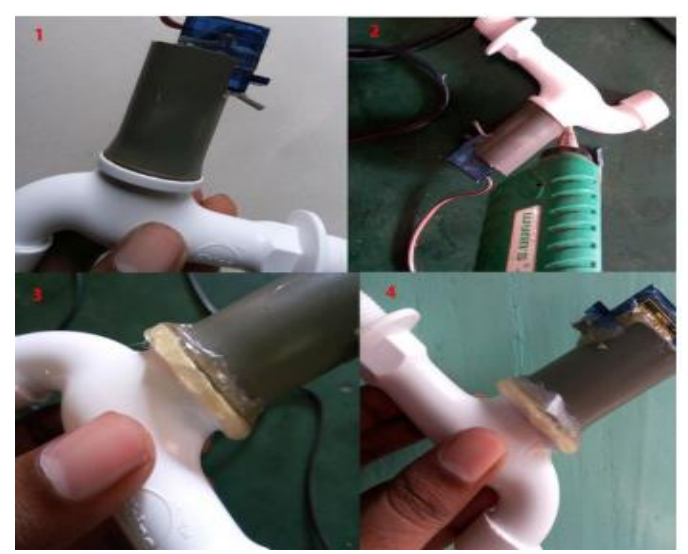

Gambar 6. Merekatkan pipa servo ke kran Air

\section{d. Membuat Modul Sensor}

Membuat sirkuit sensor sesuai dengan rangkaian pada Gambar 7 . Selanjutnya, menyolder komponen ke PCB dan kemudian memotong timah ekstra menggunakan pemotong diagonal. Kemudian menyolder tiga kawat ke VCC, GND dan Signal point dari PCB. Satu hal yang harus diperhatikan, menyambungkan dioda penerima IR dengan bias terbalik.

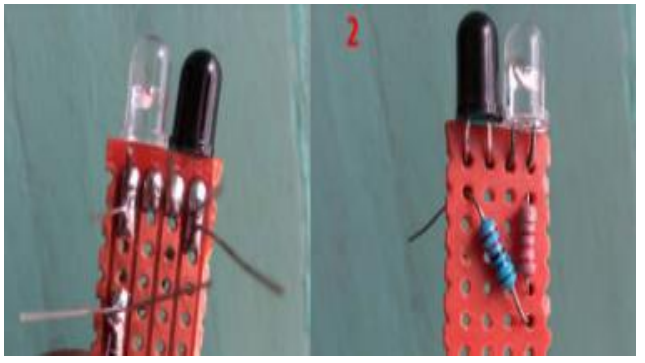

Gambar 7. Rangkaian IR Transmitter dan Receiver [2]

\section{e. Memasang Modul Sensor ke Keran Air}

Memasang modul sensor yang dibuat ke sisi bawah keran air sesuai Gambar 8 menggunakan lem panas.

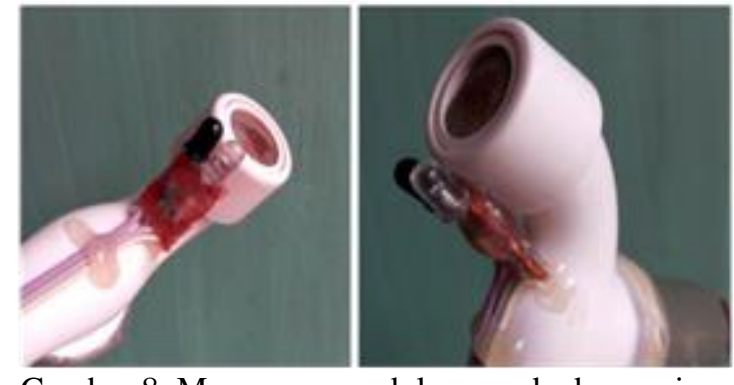

Gambar 8. Memasang modul sensor ke keran air

\section{f. Membuat Program dan meng upload ke Mikrokontroller.}

Pemrograman Arduino Uno menggunakan software Arduino. Software Arduino yang akan digunakan adalah driver dan IDE. IDE Arduino adalah software yang ditulis dengan menggunakan Java IDE Arduino.

Aplikasi Arduino Uno sebagai pemrogram dan menjalankan perintah yang di buat. Dengan melalui sensor IR membaca gerak tangan manusia sebagai sinyal input lalu diperoses Arduino. Setelah di proses Arduino akan mengirim berupa perintah ke motor servo. Motor servo akan menggerakkan membuka keran air dan akan tertutup jika tangan dijauhkan dari sensor IR.

\section{g. Hasil Akhir}

Hasil akhir dari perancangan setelah semua modul dijadikan satu menjadi sistem keran otomatis diperlihatkan pada Gambar 9.

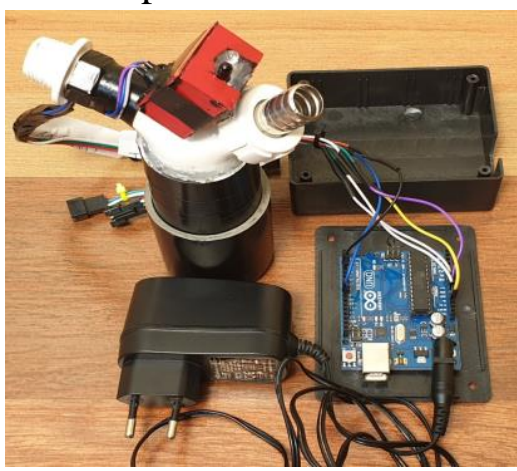

Gambar 9. Hasil akhir Sistem Keran Otomatis

\section{h. Dihubungkan ke sumber air}

Setelah sistem keran otomatis selesai dipasang pada sumber air seperti pada Gambar 10. 


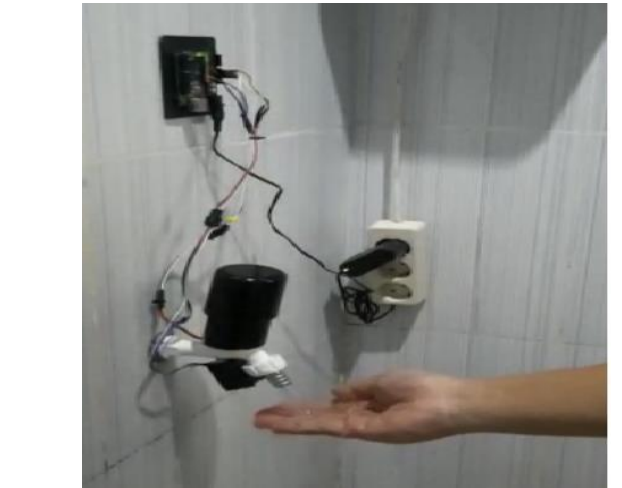

Gambar 10. Keran otomatis terpasang pada sumber air

Selain pembuatan keran otomatis yang diberikan pada sekolah MI Muhammadiyah 1, diberikan pula keperluan penunjang sarana lainnya untuk PHBS yaitu sabun cuci tangan, sanitizer, disinfektan dan semprotannya, serta kuota paket data bagi 21 siswa yang kurang mampu untuk mendukung proses belajar daring di masa pandemi ini. Agar siswa nantinya jika sudah diijinkan masuk sekolah kembali selalu ingat untuk menerapkan PHBS, diberikan pula poster dan banner tentang PHBS yang akan dipasang di tempat yang mudah terlihat, berikut buku pedoman juga tentang PHBS.

\section{Kesimpulan}

Pengabdian masyarakat program studi Telekomunikasi jurusan teknik Elektro di sekolah Madrasah Ibtidaiyah Muhammadiyah 1 Beji Timur telah dilaksanakan dengan membuat tempat cuci tangan dan pemberian sarana penunjang PHBS lainnya. Selain itu sesuai dengan keilmuannya dalam bidang teknik elektro, pada program pengabdian ini juga dibuat suatu keran otomatis menggunakan sensor IR untuk menerapkan PHBS dalam masa pandemi Covid-19. Keran otomatis dirancang agar jika cuci tangan tidak perlu memutar keran tetapi cukup mendekatkan tangan pada sensor yang dipasang pada keran dan air akan mengalir. Jika tangan di jauhkan dari keran maka air akan berhenti mengalir.

\section{Ucapan Terimakasih}

Penulis mengucapkan terimakasih kepada Unit Penelitian dan Pengabdian Masyarakat Politeknik Negeri Jakarta yang telah mendanai pengabdian ini, dengan nomor kontrak :

\section{6/PL3.18/SPK/2020}

\section{Daftar Pustaka}

[1] Sutris Astari, Rozeff Pramana.St.,MT, Deny Nusyirwan.,Msc2. "Kran Air Wudhu' otomatis Berbasis Arduino Atmega 328". Jurnal umrah.

[2] https://jurnal.umrah.ac.id/wpcontent/upload/2013/Sutris-Astari080120201029.pdf

[3] Muhammad Hidayatullah, Laili Mardiana, Wahyudi. (2016). "Sistem Kendali Keran Wudhu Otomatis Menggunakan Sensor Passive Infra Red (PIR) Berbasis Mikrokontroler Atmega8535 untuk Menghemat Penggunaan Air". Jurnal Tambora, Vol 1 No. 2, Juni 2016.

[4] Hafizur Rizki, Wildian. (2015). "Rancang Bangun Sistem Wastafel Otomatis Berbasis Mikrokontroler Atmega8535 Dengan Menggunakan Sensor Fotodioda". Jurnal Fisika Universitas Andalas, Vol. 4, No. 2, April 2015, ISSN 2302-8491

[5] Romi Shaputra, Pamor Gunoto, Muhammad Irsyam. (2019). "Kran Air Otomatis Pada Tempat Berwudhu Menggunakan Sensor Ultrasonik Berbasis Arduino Uno". Jurnal Sigma Teknika, Universitas Riau Kepulauane, Vol.2, No.2 : 192-201 November 2019- ISSN 2599-0, P ISSN 2614-5979. 